\title{
Chile promises to try harder over VLT dispute
}

Garching. A dispute over the ownership of land in Chile on which the European Southern Observatory (ESO) is building the world's largest optical telescope has come a step closer to resolution with a promise by the Chilean government to take steps to protect ESO's right to continue its work unhindered.

The five-year dispute has delayed construction work in preparation for the DM570 million (US\$800 million) Very Large Telescope (VLT), on Mount Paranal in northern Chile, and has led ESO to consider moving the operation to another country (see Nature 370, 494; 1994).

Last week, the government issued a statement promising to seek a clear ruling from the country's Senate on ESO's immunity from national laws. Riccardo Giacconi, ESO's director general, has welcomed the move, which came after a week of hard negotiation between himself, the foreign ministry and the president of Chile.

But he adds that ESO will not abandon its studies of ways of pulling out of Chile for at least another two months, during which it should become clear whether the government's promise will be fulfilled.

At the same time as announcing the government's commitment to protect construction of the VLT, José Miguel Insulza, the Chilean foreign minister, signed with Giacconi a supplementary agreement to ESO's original 1963 treaty with Chile.

Drawn up after complaints of unfair treatment by Chilean scientists and workers, the new agreement includes two concessions made by ESO. The agreement guarantees privileged viewing time on all ESO telescopes - including the VLT - for Chilean astronomers, and that ESO will respect national labour laws which, for example, confer rights to free collective bargaining.

The agreement reiterates ESO's immunity from national law and specifies that this immunity applies to all ESO sites in Chile. This is the key issue in the affair, as ESO's immunity has not been observed by the judicial system. The courts have not yet decided whether they accept the immunity agreement signed by the government.

The VLT site around Mount Paranal in northern Chile was donated by the Chilean government to ESO in 1988 in the belief that the site constituted public land. But two years later a powerful local family, the Latorres, claiming ancestral ownership of the land, sought compensation from the government through the courts.

Several injunctions to stop construction work at Mount Paranal have been issued at regular intervals over the last year, the latest one in January. The situation came to a head last month when a court official, under police escort, entered ESO premises to take note of work carried out in defiance of the courts (see Nature 374, 484; 1995).

Citing its immunity from local legal disputes, ESO has - after complying for three weeks with the first injunction - ignored further court orders to stop work. The response to the first injunction "was intended as a gesture of good will”, says Giacconi. It will never be repeated, he adds .

ESO estimates that the delays could add between DM20 million and DM50 million to the final VLT bill, largely as a result of the Latorre family's influence. ESO officials cite

\section{IMAGE UNAVAILABLE FOR COPYRIGHT REASONS}

Very Large Telescope: delays could increase construction costs by up to $\$ 36$ million.

numerous occasions when building materials have been held up in customs, and this and other delays has made it impossible for ESO to keep to schedule.

ESO has long complained that the Chilean government has taken no practical steps to defend its immunity, despite continual verbal reassurances. The root of the government's hesitancy is a power struggle between the government and the judicial

According to Rodrigo de Castro, an ESO system, which are constitutionally separate

advisor based in Chile, the government has faced two options: to plead ESO's case to the Supreme Court through the state defense council, an group of lawyers nominated by the government to defend the Chilean state, or to ask the Senate to rule on which body should have precedence.

But so far it has avoided such confrontational measures, afraid of inflaming the dispute over the issue. "Until now the government had always been very vague on its intentions," says de Castro. "But now it has said that it will ask for a Senate ruling.

品 This is something quite new for us."

ESO remains cautious. At an extraordinary meeting of the ESO council last week, delegates from the organization's eight member states agreed to give the Chilean government two months to demonstrate that it genuinely intends to resolve the land ownership dispute.

Delegates also agreed to set up a formal working group to investigate other possible sites for the telescope if Chile fails to deliver on its promise. One alternative is a site in Namibia owned by Germany's Max Planck Society. The working group will also consider potential sites in the northern hemisphere, and will report back to June's council meeting, which will decide whether the VLT should stay or move.

But there are strong grounds for optimism that the telescope, which consists of four, eight-metre optical dishes and three smaller telescopes, will still be built in Chile. Already, there have been two indications that the government is taking its new promise seriously. First, a second police visit to the construction site - threatened by the local court - did not materialize.

Furthermore, a court order issued in April, instructing customs officials not to release technical and building materials for the VLT, has been lifted. Alison Abbott

\section{India seeks source of plague 'peculiarities'}

New Delhi. The Indian government, concerned that last year's outbreak of plague in Surat may have been caused by a new strain or mutant of Yersinia pestis, is seeking the help of foreign microbiological laboratories in precisely identifying the culprit organism with the use of DNA fingerprinting techniques.

Government officials say the analysis will take up to two months to complete. As a result, a report on the outbreak by a committee of experts, previously due to be submitted by 30 April, is expected to be delayed by three months.

In its preliminary report, the committee, headed by Vulimiri Ramalingswama, confirmed that the outbreak was indeed plague, on the basis of $Y$. pestis isolated from two cultures (see Nature 373,
$650 ; 1995)$. To confirm these findings, the health minister now wants the strain to be identified by at least three international laboratories.

According to health ministry officials, detailed identification of the strain is essential because of peculiarities about the epidemiology of the Surat outbreak. Only about 20 deaths in Surat could be attributed to pneumonic plague, and despite being highly infectious - the disease did not spread outside the town.

"The genetic typing will throw light of whether Surat was truck by a non-virulent mutant," says U.V.S. Rao, a microbiologist with the National Institute of Communicable Diseases in Delhi. "If that is found to be the case, we want to know where this strain came from." K.S. Jayaraman 